\title{
Interest Free Banking: A Case Study in Pakistan (1980-2010)
}

\author{
Muhammad Faseeh ullah khan \\ (PhD Scholar, Hamdard Institute of Education and Social Sciences, Hamdard University,Karachi- Pakistan)
}

\begin{abstract}
A number of economic concepts and techniques were applied in early Islamic banking including Mufawada, Mudarabah and Al-mal as existed in the medieval Islamic world. Interest free banking attracts more attention because of the political interest. The most controversial issues about interest free banking are the profit and loss sharing formula (Concept of Mudarabah). Disenchantment with the value neutral capitalist and socialist financial systems prompted not only Muslims but also others to look for ethical values in their financial dealings, and in the west some financial organizations have opted for ethical operations. It is in the course of brain storming for proffering solution to unpalatable state of our economy's financial system that the prescribe for Islamic banking (Non-interest banking) in Pakistan is being agitated for. The focus of this project is to assess and overview of Islamic banking and finance in Pakistan. This research work is an historical research and based on secondary data.
\end{abstract}

Keywords: Riba, Shariah, Banking, Conventional, Banks, Islamic Banks.

\section{INTRODUCTION}

Islamic banking has been defined as banking in consonance with the ethos and value system of Islam and governed, in integration to the conventional good governance and jeopardizes management rules, by the principles laid down by Islamic Shari'ah. Interest free banking is a narrow concept denoting a number of banking instruments or operations, which evade interest. Islamic banking, the more general term is expected not only to evade interest-predicated transactions, precluded in the Islamic Shari'ah, but additionally to eschew unethical practices and participate actively in achieving the goals and objectives of an Islamic economy.

Islam was the basis of creation of an independent state within the undivided Indo-Pak Sub-Continent. Since its creation, the people of Pakistan have held the demand for elimination of Riba from the financial system of Pakistan on the basis of Islamic precepts. All Constitutions of Pakistan have incorporated, within the principles of policy, the reducing of Riba as an important subject of the State policy. Quaid-e-Azam, the father of the nation, in his speech at the occasion of the establishment of State Bank of Pakistan, had expressed the desire for changing an Islamic system of banking.

Islam is not simply one of the greatest monotheistic religions, signifying submission to the will of Allah, but as system of life in entirety. It prescribes a complete code of conduct for every day human life in all its spheres and manifestations. It does not confine itself to a spiritual relationship between man and Allah or describes the Almighty only with a transcendental reference but also regulates, in right proportions, an interactive relationship between man and man, and between man and society with moral, political and economic genesis. As a result, it is a religion lived in everyday life and no Muslim is in any doubt as to exactly how he should carry on the events of his day Aftab M (1986).

\subsection{Interest}

(Riba) Interest (Riba) Free Banking is a basic institution and concept of the Islamic banking. It deals with the primal professional and ethical standards that exclude the "Muslims" from paying or receiving any kind of interest but not encouraged the revenue generating activities or money raving businesses. Islamic Banking and Finance system greatly respect all types of business which don't involve interest (Riba) or usury. $R i b a$ or usury is the charging of interest on the loan. Riba technically means "Any excess benefit derived on a loan over and above the principal". Therefore, definition of Riba encompasses interest and usury taken on consumption or commercial loans as well.

\subsection{Definition Of Riba}

The word "Riba" means excess, increase or addition, which correctly interpreted according to Shari'ah terminology, implies any excess compensation without due consideration does not include time value of money.

This concept of Riba is taking from the Quran and is unanimously accepted by all the Islamic scholars. There are two types of Riba, identified to date by these scholars namely 'Riba An-Nasiyah' and 'Riba Al Fadl'. 'Riba An-Nasiyah' is defined as excess, which results from predetermined interest (sood) which a lender receives over and above the principle (RasulMaal). 'Riba Al Fadl' is defined as the excess compensation 
without any consideration resulting from a sale of goods. The Islamic system order based on a set of principles constituting the concept and philosophy as enunciated explicitly in the Quran. This philosophy provides what can be understood as the Islamic system of social justice.

Plato and Aristotle had also opposed the concept of interest in the era of before Christ. Interest was also prohibited in the preliminary teachings of Jews and Christians.

Modern economists have also opposed the interest. The famous English economics expert Keynes (1936), who is globally recognized as an expert of modern economics, has first time expressed his views on the point that unless the interest is abolished in some un-vexatious way, unemployment could not be eradicated from the world, rather, he insisted that the world would not bear the long-run idleness which is connected with the capitalism. Lord Keynes writes in a book that the rate of interest will have to be diminished in order to eradicate unemployment. Lord Keynes said that for a developed economy, interest rate should be zero. It means according to Lord Keynes there should be no interest in a model economy. The interest is an instrument of exploitation for a common person and nations, and for this purpose the detailed study under the title "The protocols of the learned elders of Zions," can be perused.

\subsection{Types of Riba}

1.3.1 Riba An-Nasiyah 'Riba An-Nasiyah' is defined as excess, which results from predetermined interest (sood) which a lender receives over and above the principle.(RasulMaal)

1.3.2 Riba Al Fadl 'Riba Al Fadl' is defined as the excess compensation without any consideration resulting from a sale of goods.

\section{Review of Literature}

After its first introduction on experimental basis in a small town of Egypt in 1963, many Islamic Banks, both with letter and spirit, were established in the Middle Eastern and Asian regions. The growth of Islamic banking has been increasing ever since, not only in terms of number of countries it is operating in but also in term of areas of finance it has ventured in El Gamal (2006). In three decades, Islamic banks have grown in number as well as in size worldwide and are being practiced on even more intensive scale. Some countries like Sudan and Iran, have converted their entire banking system to Islamic banking. In other countries where conventional banking is still dominating the Islamic Banking is operating alongside. Today, Islamic banks are operating in more than sixty countries (Aggarwal and Yousaf (2000)). Islamic Banking and Finance is growing at between 10\%-15\% per annum and is boasting global assets in excess of $\$ 1$ Trillion. A recent survey indicated that there are more than 160 Islamic financial institutions existing worldwide Dar.

Gradual and steady spread of the Islamic banks over time over the world is a lucid manifestation of success and the symbolic growth rate is the hallmark of this emerging market. Being fastest growing segment of the credit market in Muslim countries, market share of Islamic banks in Muslim countries has risen from $2 \%$ in the late 1970s to about 15 percent today. Islamic banking is getting popularity, warm welcome, and appreciation also by non-Muslims in Muslim and non-Muslim countries.

The main objective of Islamic bank is to present the Muslim the way of getting returns on their investment in according with Shari'ah and Muslims law. . Islamic banking is the system of banking consistent with principles of Islamic law (Shari'ah) and guided by Islamic economics. Islamic economics is referred to that body of knowledge which helps realize human well-being through an allocation and distribution of scarce resources that is in conformity with Islamic teachings without unduly curbing individual freedom or creating continued macroeconomic and ecological imbalances. A key element of Islamic economics is distribution of equitable rewards to the different factors of production. Islamic economic system seeks system of Redistributive justice where concentration of wealth in a few hands is countered and flow of money into the economy is fluent. Islamic banking is, therefore, seen as a lynchpin to achieving the economic and social goals of the Islamic economic system.(Source: Bank Alfalah).The thrust of Islamic banking is founded on the desire to submit to the Divine Instructions on all transactions, particularly those involving exchange of money for money.

However, it would be quite unfair to limit Islamic banking to elimination of Riba only. Riba is but one of the major undesirable elements of an economic transaction, the others being Gharar (risk or uncertainty) and Qimar (speculation). While elimination of these objectionable aspects in a transaction is indeed a critical aim of Islamic banking, it is by no means its ultimate objective. According to some, usury or excessive and exploitative charging of interest; while according to others, interest per se - is forbidden by the Qur'an. For example: It has been argued in vain for long in some circles that the prohibition in Islam is that of excessive interest only or that it is the interest on consumptive loans that has been forbidden and as such loans extended for commercial purposes are entitled to an excess over the principle amount lent. Such tendentious arguing fails to give due understanding to versus $(2 / 278-279)$. However, this does not mean that Islam prohibits any gain on principle sums. In Islam, profit is the recognized reward for capital. When capital employed in permissible business yields profit that profit (excess over capital) becomes the rightful and just claim of the owner of the capital. 
As with all things Islamic, the origination of Islamic finance goes back to the time of Prophet Muhammad (Peace be upon Him). The Prophetic example was the very epitome of fair trade. Refraining from usury, ensuring transparency in transactions, and total honesty entitled him Al-Amin (The trustworthy) in pre-Islamic Arabia (Sufyan).

These banks were functioning essentially as saving-investment institutions rather than as commercial banks. Although its charter made no reference to Islam or Shari'ah (Islamic law), Nasir Social Bank, established in Egypt in 1971, was declared an interest free commercial bank Arif (1988).

In the seventies, with letter and spirit, a number of Islamic banks were established in the Middle East, e.g., the Dubai Islamic Bank (1975), the Faisal Islamic Bank of Egypt (1977), the Faisal Islamic Bank of Sudan (1977), and the Bahrain Islamic Bank (1979), to mention a few. A number of banks were also established in the Asia-Pacific region in response to these winds of change, e.g., The Philippine Amanah Bank (PAB) was established in 1973 as a specialized banking institution by Presidential Decree without reference to its Islamic character in the bank's charter. The PAB is not strictly an Islamic bank; nevertheless, efforts are underway to convert the PAB into a full-fledged Islamic bank Mastura (1988). Islamic banking was introduced in Malaysia in 1983. The success of the Tabung Haji also provided the main thrust for establishing Bank Islam Malaysia Berhad (BIMB), which represents a full-fledged Islamic (commercial) bank in Malaysia. The Organization of Islamic Countries (OIC), established Islamic Development Bank (IDB) in December 1973. The IDB not only provides fee-based financial services but also provides financial assistance on profit-sharing bases to its member countries (Source: IDB). Reference should also be made to some Islamic financial institutions established in countries where Muslims are a minority. There was a proliferation of interest-free savings and loan societies in India during the seventies Siddiqi (1988). This difference that Introduces the element of mutuality in Islamic banking makes its depositors as customers with some ownership of right in it Dar and Presley.

Islamic banks are similar to those of non-Islamic banks in that both offer similar (financial) services and play a pivotal role in the economic development of their societies. But they are different in that Islamic banks, unlike non-Islamic banks, are bound to follow Islamic Shari'ah in their operations. For instance, according to Islamic Shari'ah exploitative contracts based on Riba (usury or interest) or unfair contracts that involve risk or speculation are unforeseeable. Islamic banking and conventional banking differs in that while the conventional banking follows conventional interest-based principle, the Islamic banking is based on interest-free principle and principle of Profit-and-Loss (PLS) sharing in performing their businesses as intermediaries Arif (1988). Rationale behind prohibition of interest and the importance of PLS in Islamic banking has been discussed in many Islamic economics studies. Moreover, Islamic PLS principle creates the relationship of financial trust and partnership between borrower, lender, and intermediary Yudistira (2003).

In Malaysia a study conducted on finding causal relationship between Islamic and conventional banking instruments. The procedures involved the Granger causality test and unit root test. And the finding of the study shows that the conventional TDRs Granger causes Islamic TDRs in all respects. And they conclude from their study that Islamic banking should consider interest rates before adjusting their profit rates .A study that conducted by Humayon and Presley (1998), have provide a bright way to the Islamic financial; implementing and research authority that it would not be good to act as isolated part of literature from western literature, but Islamic financial can perform more better if; they adopted the supportive arguments that is found in the western literature. It would too encourage the focus of west on the new modal of Islamic finance for research Humayon and Presley (1998).

The principle of Mudaraba based on Shari'ah was invoked systematically by Uzair (1955). His principal contribution lay in suggesting Mudaraba as the main premise for 'interest less banking'. However, his argument that the bank should not make any capital investment with its own deposits rendered his analysis somewhat impractical.

It emerges from all this that Islamic banking has three distinguishing features: (a) it is interest-free, (b) it is multi-purpose and not purely commercial, and (c) it is strongly equity-oriented. The literature contains hardly any serious criticism of the interest-free character of the operation, since this is taken for granted, although concerns have been expressed about the lack of adequate interest-free instruments. There is a nearconsensus that Islamic banks can function well without interest. A recent International Monetary Fund study by Iqbal and Mirakhor (1987) has found Islamic banking to be a viable proposition that can result in efficient resource allocation. The study suggests that banks in an Islamic system face fewer solvency and liquidity risks than their conventional counterparts. The multi-purpose and extra-commercial nature of the Islamic banking operation does not seem to pose intractable problems. The abolition of interest makes it imperative for Islamic banks to look for other instruments, which renders operations outside the periphery of commercial banking unavoidable. Such operations may yield economies of scope. But it is undeniable that the multipurpose character of Islamic banking poses serious practical problems, especially in relation to the skills needed to handle such diverse and complex transactions Iqbal and Mirakhor . 
The stress on equity-oriented transactions in Islamic banking, especially the Mudaraba mode, has been criticized. It has been argued that the replacement of pre-determined interest by uncertain profits is not enough to render a transaction Islamic, since profit can be just as exploitative as interest is, if it is 'excessive' Naqvi (1981). Naqvi has also pointed out that there is nothing sacrosanct about the institution of Mudaraba in Islam. Naqvi maintains that Mudaraba is not based on the Qur'an or the Hadith but was a custom of the pre-Islamic Arabs. Historically, Mudaraba, he contends, enabled the aged, women, and children with capital to engage in trade through merchants for a share in the profit, all losses being borne by the owners of capital, and therefore it cannot claim any sanctity. The fact remains that the Prophet raised no objection to Mudaraba, so that it was at least not considered un-Islamic.

The distribution of profit in Mudaraba transactions presents practical difficulties, especially where there are multiple providers of capital, but these difficulties are not regarded as insurmountable. The Report of Pakistan's Council of Islamic Ideology (CII 1983) has suggested that the respective capital contributions of parties can be converted to a common denominator by multiplying the amounts provided with the number of days during which each component, such as the firm's own equity capital, its current cash surplus and suppliers' credit was actually deployed in the business, i.e., on a daily product basis. As for deposits, profits (net of administrative expenses, taxes, and appropriation for reserves) would be divided between the shareholders of the bank and the holders of deposits, again on a daily product basis.

Savings deposits, too, are accepted on the basis of Al-Wadiah, but 'gifts' to depositors are given entirely at the discretion of the Islamic banks on the minimum balance, so that the depositors also share in profits. Investment deposits are invariably based on the Mudaraba principle, but there are considerable variations.

Thus, for example, the Islamic Bank of Bangladesh has been offering PLS Deposit Accounts, PLS Special Notice Deposit Accounts, and PLS Term Deposit Accounts, while Bank Islam Malaysia has been operating two kinds of investment deposits, one for the general public and the other for institutional clients.

\section{TOOLS OF ISLAMIC BANKING}

There are different tools which are used in Islamic banking. A brief Introduction of these tools is as follows:

\subsection{LEASING}

\subsubsection{DEFINITION}

A legal document outlining the terms under which one party agrees to rent property from another party. A lease guarantees the lessee (the renter) use of an asset and guarantees the lessor (the property owner) regular payments from the lessee for a specified number of months or years. Both the lessee and the lessor must uphold the terms of the contract for the lease to remain valid. A lease of immovable property of right to enjoy such property, made for a certain time express or implied, or in perpetuity, in consideration for a price paid or promised or of money a share of crops, service or any other thing of value, to be rendered periodically or on specified occasions to the transferor by the transferee, who accepts the transfer on such terms:

\section{Transferor}

The transferor is the lessor.

Transferee

The transferee is called lessee.

Price

The price is called premium.

Rent

The money, share or other thing to be so rendered is called the rent.

Essentials element of lease

Following are essentials elements of lease.

(i) Immoveable property Lease must relate to immoveable property.

(ii) Fixed duration of enjoyment: Such enjoyment of right of property must be for fixed duration.

(iii) Transfer of right: There must be transfer of such right of enjoyment.

(iv) Consideration: It must be for consideration.

(v) Acceptance: The transfer must be accepted by the transferee.

\section{KINDS OF LEASE}

Following are kinds of lease.

(i) Lease for certain time.

(ii) A periodic lease.

(iii) Lease in perpetuity.

\subsubsection{WORKING}

\subsubsection{BASIC TYPES OF LEASING}

We use two types of leases in business. 


\subsubsection{OPERATING LEASE}

A contractual arrangement by which the lessee agrees to make a periodic payments to the lesser, often for 5 years, to obtain an assets services generally, the total payment over the term of lease are less than the lessor initial cost of lease asset.

\subsubsection{FINANCE LEASE}

A long term lease than an operating lease that is obligates the lessee to make payments for the use of an asset over a predefined period of time, the total payments over the term of lease are greater than the Lessor initial cost of the leased asset.

\subsubsection{LEASING IN PAKISTAN}

In Pakistan leasing was introduced as an alternative debt financing which was being interest based is prohibited in Islam. As such leasing has been approved by the religious Board as one of the Islamic modes of financing. The first leasing company was established in 1985 in public sector National Development Leasing Corporation Since then leasing sector has been progressing at a very high pace both in terms of increase in number of leasing companies. Presently there are 32 companies were listed on Karachi stock exchange. All the 32 companies are listed paid-up capital of 32 leasing companies almost RS 4.3bn. Usually the leasing companies are the secondary lenders as they borrow to land. That is why they are in expensive business.

According to the page (Pakistan \& gulf economist) is estimated that leases accounting to RS 25000 billion have been disbursed to date 01-01-1996.

\subsubsection{MAJOR LEASING COMPANIES IN PAKISTAN}

\section{i. Askari Leasing}

ii. English Leasing

iii. Dawood Leasing, Trust Leasing

iv. National Asset First Leasing NDLC Union Leasing

v. Universal Leasing Pacific Leasing

vi. ORIX Leasing Lease Pak. Ltd.

\subsubsection{IJARAH}

i. Ijarah means to sell usufruct of an asset on rent.

ii. The term is also used in hiring someone to do a job or service.

iii. In Ijarah, right of use of a property is transferred to another person for a consideration.

iv. It is an Islamic alternative for leasing a tangible asset.

\subsubsection{APPLICATION OF IJARAH IN ISLAMIC FINANCE}

\section{Consumer Financing}

i. Using Reverse Murabaha as an alternative to Credit Cards

Corporate Financing

ii. Industrial Raw Material - Local and Imported

iii. Industrial Machinery - Local and Imported

iv. Plant \& Equipment - Local and Imported

v. Agricultural Output - Local and Imported

vi. Industrial Output - Local and Imported

\subsubsection{IJARAH IN ISLAMIC FINANCE}

i. The lease period starts when the asset has been delivered by the lessor in a usable condition.

ii. The bank (Lessor) bears the ownership related costs and the customer (Lessee) bears the usage related cost.

iii. Insurance, installation, import duty, delivery charges are paid by the bank and are added in its cost and are taken into account when quoting rentals to the customer at the time of entering into the Ijarah agreement.

iv. If the asset is destroyed or becomes unusable, the bank stops taking rent and does not charge rent for that period.

v. Penalty for late payment is charged for maintaining financial discipline and is paid to charity.

vi. The asset/property remains in the ownership of the bank until the bank sells the asset to the customer in a separate agreement.

vii. The client is not obliged to buy the asset at the end of the lease period. However, in some countries, banks now take an undertaking from the client to purchase the asset from the bank when the lease period expires. 


\subsubsection{PROCESS FLOW OF AN IJARAH TRANSACTION}

The process flow is as follows:

i. The customer approaches the bank for obtaining an asset on lease.

ii. The customer undertakes to make periodic lease payments for the lease period.

iii. Lease agreement and agency agreement is signed.

iv. The bank leases the asset and the customer starts using the asset and pays rent for each period.

$\mathrm{v}$. In the end, the customer can purchase the asset from the bank by way of a separate purchase agreement.

\subsubsection{APPLICATION OF IJRAH IN ISLAMIC FINANCE}

\section{Consumer Financing}

a. Vehicle Financing

i. Car, Motorcycle, Rickshaw, Truck etc.

b. Consumer Appliance Financing

i. Fridge, Refrigerator, Microwave, UPS etc.

Corporate Financing

a. Industrial Machinery - Local and Imported

i. Plant \& Equipment - Local and Imported

\subsubsection{IJARA (Rent)}

\section{BASIC RULES OF IJARA}

1. Transferring of usufruct not ownership to another person for an agreed price, at an agreed consideration.

2. Subject of lease valuable, Identified and Quantified

3. Consumable things cannot be leased out anything which cannot be used without consuming cannot be leased out; e.g., money, wheat etc.

4. All Liabilities of ownership are borne by lessor corpus of leased property remains in the ownership of the seller. Period of lease .Must be determined in clear terms at the time of contract

5. Lease for specific purpose only if no specific purpose is identified in the agreement, then it can be used for any purpose for which it is used in normal course

6. Lessee as Ameen, The lessee is liable to compensate the lessor for every harm to the leased asset caused by any misuse or negligence. The leased asset shall remain in the risk of the lessor throughout the lease period.

7. Lease of jointly owned property is permitted and rentals shall be distributed between all the joint owners according to the proportion of their respective shares in the property.

8. Determination of Rental the lessor cannot increase the rent unilaterally, and any agreement to this effect is void. The lease period shall commence from the date on which the leased asset has been delivered to the lessee. Rental will be charged when the Leased asset is handed over to the lessee. Purchase of Assets and Lease

\subsection{MUDARABAH}

\subsubsection{DEFINITION}

It is a partnership in profit between capital and work. It may be conducted between investment account holders as providers of funds and the Islamic bank as a Mudarib. The Islamic bank announces its willingness to accept the funds of investment amount holders, the sharing of profits being as agreed between the two parties, and the losses being borne by the provider of funds except if they were due to misconduct, negligence or violation of the conditions agreed upon by the Islamic bank. In the latter cases, such losses would be borne by the Islamic bank. A Mudaraba contract may also be concluded between the Islamic bank, as a provider of funds, on behalf of itself or on behalf of investment account holders, and business owners and other craftsmen, including farmers, traders etc. Mudaraba differs from what is known as speculation which includes an element of gambling in buying and selling transactions. (It is to the former that this standard applies). Mudarabah is a special kind of partnership where one partner providers the capital (rabb-ul-maal) to the other (Mudarib) for investment in a commercial enterprise.

\subsubsection{TYPES OF MUDARABAH}

i. Al Mudarabah Al Muqayyadah (Restricted Mudarabah)

ii. AlMudarabah Al Mutlaqah (Unrestricted Mudarabah)

\subsubsection{MUDARABAH}

It is a partnership in which there are two partners i.e. Rabb-ul-Maal and Mudarib. Rabb-ul-Maal is the investing party which contributes capital in the partnership. Mudarib is the working party which contributes by rendering services in the partnership. 
Rabb-ul-Maal is the investing party which contributes capital in the partnership. In case of profit, Rabb-ul-Maal shares in profit based on profit sharing ratio agreed between the Rabb-ul-Maal and the Mudarib. In case of loss, Rabb-ul-Maal bears the complete risk of all financial losses.

\section{ROLE OF MUDARIB}

Mudarib is the working party which contributes services in the partnership. In case of profit, Mudarib shares in profit based on profit sharing ratio agreed between the Rabb-ul-Maal and the Mudarib. In case of loss, Mudarib loses the remuneration for his services. Mudarib is entitled to receive Ujrat-e-Misl (equivalent wage) if the loss is not caused by his willful neglect.

\section{Interest Free Banking In Pakistan: (Historical Review)}

Islamic banking has been defined as banking in consonance with the ethos and value system of Islam and governed, in addition to the conventional good governance and risk management rules, by the principles laid down by Islamic Shari'ah. Interest free banking is a narrow concept denoting a number of banking instruments or operations, which avoid interest. Islamic banking, the more general term is expected not only to avoid interest-based transactions, prohibited in the Islamic Shari'ah, but also to avoid unethical practices and participate actively in achieving the goals and objectives of an Islamic economy.

Since Pakistan started with an approach to convert the whole system into Islamic one, a number of amendments in relevant laws were introduced providing legal cover for Islamic financial products and services. Similarly, some new laws were introduced to allow new financial institutions or facilitate the existing ones. The legal and regulatory infrastructure developed during that era has proved to be invaluable asset as we keep on charting the present landscape of the industry today on the same.

\subsection{ISLAMIC BANKING CONCEPTS AND PRACTICES}

In this section, we first examine basic Islamic concepts as well as the profit-and-loss sharing (PLS) paradigm in Islamic banking. We then provide a discussion of Islamic banking practices in Malaysia.

\subsection{ISLAMIC BANKING CONCEPTS AND PARADIGM}

In Islam, there is no separation between mosque and state. Business, similarly, cannot be separated from the Islamic religion. The Shari'ah (Islamic law) governs every aspect of a Muslim's religious practices, everyday life, and economic activities. Muslims, for example, are not allowed to invest in businesses considered non-halal or prohibited by Islam, such as the sale of alcohol, pork, and tobacco; gambling; and prostitution. In Islamic contracting, Gharar(uncertainty and risk) is not permitted, i.e., the terms of the contract should be well defined and without ambiguity. More importantly, Muslims are prohibited from taking or offering Riba. What constitutes Riba, however, is controversial and has been widely debated in the Islamic community. Some view riba as usury or excessively high rate of interest. But the majority of Islamic scholars view Riba as interest or any pre-determined return on a loan. The basis for the prohibition of Riba in Islam may be traced to the common medieval Arabic practice of doubling the debt if the loan has not been repaid when due. In Islamic economics, the lender should bear the risk of the venture with the borrower because it is deemed that neither the borrower nor lender is in control of the success or failure of a venture. Thus, a unique feature that differentiates Islamic banking from conventional banking, in theory, is its profitand-loss sharing (PLS) paradigm. Under the PLS paradigm, the ex-ante fixed rate of return in financial contracting, which is prohibited, is replaced with a rate of return that is uncertain and determined ex-post on a profit-sharing basis. Only the profit-sharing ratio between the capital provider and the entrepreneur is determined ex-ante. PLS contracts, in general, allow two or more parties to pool their resources for investment purposes and to share the investment's profit-and-loss. The PLS paradigm is widely accepted in Islamic legal and economic literature as the bedrock of Islamic financing. Islamic bank financing, which adheres to the PLS principle, is typically structured along the lines of two major types of contracts: Musharakah (joint venture) and Mudarabah (profit-sharing). Musharakah contracts are similar to joint venture agreements, in which a bank and an entrepreneur jointly contribute capital and manage a business project. The profits from the project are shared by both parties on a pre-agreed (fixed ratio) basis, but in the cases of losses, the total loss is borne by the bank. Most theoretical models of Islamic banking are based on the Mudarabah (profit-sharing) and/or Musharakah(joint venture) concepts of PLS . There are, however, other financing contracts that are permissible in Islam but not strictly PLS in nature. Such financing contracts, for example, may be based on Murabaha (cost plus), Ijarah (leasing), Bai' Muajijal (deferred payment sale), Bai' Salam (forward sale), and Istisna (contract manufacturing) concepts. Murabaha financing is based on a mark-up (or cost plus) principle, in which a bank is authorized to buy goods for a customer and resell them to the customer at a pre-determined price that includes the original cost plus a negotiated profit margin. This contract is typically used in working capital and trade financing. Ijarah financing is similar to leasing. A bank buys an asset for a customer and then leases it to the 
customer for a certain period at a fixed rental charge. Shari'ah (Islamic law) permits rental charges on property services, on the precondition that the lessor (bank) retain the risk of asset ownership. Bai' muajjal financing, which is a variant of Murabaha (cost plus) financing, is structured on the basis of a deferred payment sale, whereby the delivery of goods is immediate, and the repayment of the price is deferred on an installment or lump-sum basis. The price of the product is agreed upon at the time of the sale and cannot include any charge for deferring payments. This contract has been used for house and property financing. Bai' salam is structured based on a forward sale concept. This method allows an entrepreneur to sell some specified goods to a bank at a price determined and paid at the time of contract, with delivery of the goods in the future. Istisna contracts are based on the concept of commissioned or contract manufacturing, whereby a party undertakes to produce a specific good for future delivery at a pre-determined price. It can be used in the financing of manufactured goods, construction and infrastructure projects.

\subsection{MEASURES TAKEN FOR ISLAMISATION IN PAKISTAN}

As per Article 2 of the Constitution, Islam is the State Religion of Pakistan. The Objectives Resolution was adopted by the first Constituent Assembly in 1949; it was the preamble of the 1956, 1962 and 1973 Constitutions. It provided that no law should be enacted that is repugnant to the injunctions of Islam. It was made substantive part of the Constitution in 1985. (The Eighth Amendment of the 1973 Constitution, adopted by the National Assembly in 1985, also made room for creation of the Federal Shari'ah Court (FSC).

Creation of the Council of Islamic Ideology (CII) in 1962. The report of the CII on Elimination of Interest (June, 1980) is genuinely considered to be first major comprehensive work in the world undertaken on Islamic banking and finance.

Practically, measures taken included the introduction of Zakat (June, 1980) and Ushr (tithe) (March, 1983) and elimination of interest from the operations of Specialized Financial Institutions (July, 1979 to July, 1985) and the commercial banks (January, 1981 to July, 1985). Commercial banks transformed their nomenclature during January 1981 to June 1985 based on the 12 modes. From July 1, 1985 all commercial banking in Pak Rupees was made interest-free. However, foreign currency deposits in Pakistan and on lending of foreign loans continued as before.

However, procedure adopted by banks was declared un-Islamic by the Federal Shari'ah Court (FSC) in November 1991. The Government and some banks/DFIs preferred appeals to the Shari'ah Appellate Bench (SAB) of the Supreme Court of Pakistan. SAB delivered its judgment of December 23, 1999 rejecting the appeals and directing that laws involving interest would cease to have effect finally by June 30, 2001. However, SAB gave exemption for dealing with foreign parties on the basis of interest.

The Government, in line with directives of SAB, constituted a high level Commission and a number of tasks forces and Committees to study the prospects of transformation of Pakistan's financial system for interest based to Shari'ah compliant and to chalk out the transformation plan. However, the Government came to the conclusion that transformation of the financial system as whole was not possible in short term due to a variety of factors/reasons. Developing a viable and complete model of Islamic finance and putting it into practice was complex and difficult tasks and it would not be wise to under-estimate those difficulties and risks. Therefore, it was decided to promote Islamic banking on parallel basis with conventional system.

State Bank has issued the criteria for establishment of Islamic banks in private sector and subsidiaries and stand-alone branches by existing commercial banks to conduct Islamic banking in the country. A Musharaka-based Export Refinance Scheme has been designed by the State Bank in order to provide export finance to eligible exporters on the basis of Islamic modes of financing. Efforts are underway to develop Islamic money market instruments like Ijarah ,Sukuk to facilitate the banks in respect of liquidity and SLR management. In addition to Meezan Bank as a full-fledged Islamic bank operating exclusively on Shari'ah compliant basis, three banks are operating seven IBBs (MCB, BoK, BankAlfalah). Habib Bank Limited has also been given in principle approval for one stand-alone branch. State Bank has received applications for 24 IBBs to be opened in2004.

Anti-Money Laundering Measures: The ease with which huge sums can be transferred across the globe with a single push of a button has facilitated international trade and settlements, but the capability itself has given nightmares to the managers of developing economies trying to compete in an increasingly market based competitive environment, as also for developed economies by facilitating money laundering and terrorism. Homoud (1985) Islamic banks, by their nature, are less likely to engage in money laundering and other illegal activities such as financing of terrorism than the conventional banks. Their disclosure standards are stringent because they require the customers to divulge the origins of their funds in order to ensure that they are not derived from illegal means. Islamic financing modes are used to finance specific physical assets like machinery, inventory, and equipment. Further, the role of Islamic banks is not limited to a passive financier concerned only with timely interest payments and loan recovery. Islamic bank is a partner in trade and has to concern itself with the nature of business and profitability position of its clients. A stringer 'Know Your 
Customer' (KYC) policy is an inbuilt requirement for an Islamic bank. Before entering into a contract Islamic Knowledge of the individual or collective management and their bona fides - An internal code of ethics in negation of a singular profit objective - Awareness of the spirit and basis of governing laws and regulations. Pakistan has adopted a strategy by adopting uniform international standards to ensure fair play by all kinds of banks and financial institutions also including Islamic banks. It has also put in place stringent regulations in order to effectively curb money laundering. An Anti Money Laundering law has been developed and is in the stage of finalization. Mannan ( 1970)

\subsection{PROTECTION GRANTED TO FOREIGN COMMITMENTS}

Section 18 of the Shari'ah Act, 1991 provides that notwithstanding any other provision of this Act or any decision of any Court, financial obligations incurred and contracts made between a National Institution (which includes the government, a statutory corporation, a company, or any person in Pakistan), and a Foreign Agency (which includes a foreign Government, a foreign financial institution, foreign capital market, including a bank and any lending agency and individuals, as well as suppliers of goods and services) shall continue to remain, and be valid, binding and operative.

\subsection{CHALLENGES}

Enforcement of contracts is not effective. Inefficient system for early recovery. Ineffective code of conduct for professionals Development of Shari'ah compliant government securities. Research and development in the field of Islamic finance and economies. HR development and training to the banks staff on Islamic Banking and Finance. Education and public awareness about Islamic financial system. The acceptability of the above non-PLS modes of financing, however, has been widely debated and disputed because of their close resemblance to conventional methods of interest-based financing. Many Islamic scholars, including Pakistan's Council of Islamic Ideology, have warned that, although permissible, such non-PLS modes of financing should be restricted or avoided to prevent them from being misused as a "back door" for interestbased financing.

\subsection{COUNCIL FOR ISLAMIC IDEOLOGY}

In 1980, a think tank by the name Council of Islamic Ideology (C.I.I.), consisting of 15 eminent jurists, scholars, economist and bankers was formed. Their task was to recommend to the Federal Government all possible avenues and amendments to bring the existing laws and practices of the country in conformity with the injunctions of Islam. C.I.I., after several meetings and extensive brain storming, apart from recommendations in lieu of other civil and criminal laws, suggested to the Federal Government that an interest free banking system should be introduced in the country.

Their first recommendation was that Interest, referred to as "Riba" in the Holy Quran, based on Verses 278 and 279 of Surah Al Baqarah, is Haram. Allah Almighty and his Messenger (PBUH) has declared war on those who indulge themselves in Riba. C.I.I, recommended that instead of lending money on basis of interest/ Riba, the financing in the shape of Islamic financing Bai Muajjal (deferred sale) should be adopted.

In furtherance to the above, the Federal Government adopted the system of mark-up in January, 1981 and repealed Interest Act, 1839.On the basis of the foregoing recommendations of the C.I.I., agreed to by the Federal Government, the State Bank of Pakistan's Banking Control Department, issued Circular Nos.13 and 32, dated 20th June, 1984 and 26th November, 1984, respectively. Through the earlier circular, the intention of the government to shift the interest based banking to Islamic modes of financing was revealed. In that circular, the financial institutions/banks were barred from receiving any interest bearing deposits from July 1 , 1985. As regards the loaning, it was suggested that the banks should adopt the Islamic mode of financing, mentioned in the 1st Annexure of the circular, i.e. mark-up (BaiMuajjal), Musharika (profit loss sharing), Morabaha (hire purchase, leasing etc). The second circular barred the banks from charging mark-up on markup on overdue loans as penalty.

The C.I.I., in order to establish interest free/Riba free banking system in Pakistan, proposed amendments in the following laws:

(a) The Interest Act of 1839

(b) The Government Saving Banks Act of 1873 (Section-10)

(c) The Negotiable Instrument Act of 1881 (Sections-79, 80, 114 \& 117)

(d) The Land Acquisition Act, 1894 (concerned provisions)

(e) The Code of Civil Procedure, 1908 (concerned provisions)

(f) The Cooperative Societies Act, 1925 (concerned provisions)

(g) The Cooperative Societies Rules, 1927 (concerned provisions)

(h) The Insurance Act, 1938 (concerned provisions) 
(i) The State Bank of Pakistan Act, 1956 (Section-22(1)

(j) The West Pakistan Money Landers Ordinance, 1960 (concerned provisions)

(k) The West Pakistan Money Lenders Rules, 1965 (concerned provisions)

(1) The Punjab Money Lenders Ordinance, 1960 (concerned provisions)

(m) The Sindh Money Lenders Ordinance, 1960 (concerned provisions)

(n) The NWFP Money Lenders Ordinance, 1960 (concerned provisions)

(o) The Baluchistan Money Lenders Ordinance, 1960 (concerned provisions)

(p) The Agricultural Development Banks Rules 1961 (Rule No. 17 (1) (2) \& (3)

(q) The Banking Companies Ordinance, 1962 (Section 25 (2a\&b)) (r) The Banking Companies Rules, 1963 (Rule No.9 (2\&3)

(s) The Banks (Nationalization) Payment of Compensation Rules, 1974 (Rule 9)

(t) The Banking Companies (Recovery of Loans) Ordinance, 1979 (Section 8(2a\&b)

\section{CONCLUSION}

Financial services industry especially banking sector witnessed unprecedented growth during the last few years in every part of the world. Pakistani economy experienced an Increase in the contribution of the banking sector towards GDP due to an expansion of the market and diversification of products/service to meet customers' expectations. A large number of new banks have started operations in Pakistan. Similarly, inception of Islamic banking operations in 2002 opened new avenues to exploit the opportunities. Islamic banks are getting popularity due to interest free products, risk sharing activities and strong ties with the religion. Islamic banks work as welfare organization to promote trade and economic activities in line with the instructions of Islam to provide a number of Interest-free products/service.

The existence of Islamic and conventional banks in Pakistan created stiff competition among banks to attract and retain greater number of customers by the provision of quality services. This study examined the relationship among service quality, customer satisfaction and bank performance by comparing Islamic and conventional banks operating in Pakistan. The researcher developed and tested a model of service quality, customer satisfaction and bank performance in the light of existing literature.

It is concluded that there is significant difference in the perception of customers of Islamic banks about service quality on the basis of gender. While in case of conventional banks, there is no significant difference in the perception of male and female bank Customers. The results show that there is strong direct and positive relationship between service quality and customer satisfaction in Pakistani banking sector. The magnitude of relationship between service quality and customer satisfaction is greater in Islamic banks as compared to conventional banks. It is proved that service quality also influence the bank performance while there is weaker relationship between customer satisfaction and bank performance. However is found that that four dimensions of service quality i.e. tangibility, reliability, responsiveness and assurance have significant impact on service quality except empathy in case of Islamic banks. Similarly four dimension namely tangibility, reliability; responsiveness and empathy have significant impact on customer satisfaction in case of CB but assurance has no significant influence on customer satisfaction. The study identified significant positive impact of service quality on customer satisfaction in case of CB but a gap is identified between customer satisfaction and bank performance in case of Islamic banks. The gap between customer's satisfaction and performance of Islamic banks may be due to the lack of customer orientation.

Islamic banks are more concerned towards expansion of their branch network instead of Customer orientation. Finally, it is proved that customer satisfaction partially mediate the relationship between service quality and bank performance in Pakistan as shown by the results of structural models. The results of proposed model reflect that customer satisfaction does not play the mediating role between service quality and performance of Islamic banks. On the other hand, customer satisfaction mediates the relationship between service quality and performance of conventional banks in Pakistan.

It is concluded that managers should improve the quality of services to retain their customers as satisfied customers for long-term benefits. Similarly, they should make arrangements to enhance awareness among customers and employees of banks for improvement of their products/services to enhance performance. Islamic banks should develop marketable products according to Islamic instructions to compete with conventional banks. The study has developed an understanding about the relationship among service quality, customer satisfaction and bank performance regarding Islamic and conventional bank in Pakistan. 


\section{REFERENCES}

[1] Abdallah, A., 1987. 'Islamic banking', Journal of Islamic Banking and Finance, January-March, 4(1): 31-56.

[2] Aftab, M., 1986. 'Pakistan moves to Islamic banking', The Banker, June: 57-60.

[3] Bruce, N.C., 1986. 'Islamic banking moves east', Euro money, July: 142-5.

[4] Chapra, M. Umer, 1982. 'Money and banking in an Islamic economy' in M Ariff (ed.), above.

[5] El-Asker, A.A.F., 1987. The Islamic Business Enterprise, Croom Helm, London.

[6] Karsten, I., 1982. 'Islam and financial intermediation', IMF Staff Papers, March, 29(1):108-42.

[7] Khan, M. S.,1986.'Islamic interest-free banking', I M F Staff Papers, March, 33(1):1-27.

[8] Khan, Muhammad Akram, 1968. 'Theory of employment in Islam', Islamic Literature, Karachi, XIV (4): 5-16.

[9] Nienhaus, V., 1983. 'Profitability of Islamic PLS banks competing with interest banks: problems and prospects', Journal of Research in Islamic Economics, 1(1):37-47.

[10] Partadireja, Ace, 1974. 'Rural credit: the Ijon system', Bulletin of Indonesian Economic Studies, 10 (3): 54-71.

[11] Rahman, Fazalur, n.d. 'Riba and interest', Islamic Studies, Karachi, 3(1):1-43.

[12] Rosa, D.A., 1986. 'Islamic financial policies and domestic resource mobilisation', Savings and Development, 2:143-53.

[13] Su'ud, M. Abu, n.d. 'The economic order within the general conception of the Islamic way of life', Islamic Review, London, 55 